\title{
Ghanaian Junior High School Science Teachers' Knowledge of Contextualised Science Instruction
}

\author{
Ernest I. D. Ngman-Wara ${ }^{1, *}$ \\ ${ }^{1}$ University of Education, Winneba, Ghana \\ *Correspondence: P.O. Box 25, Winneba, Ghana. Tel: 233-244-150-836. E-mail: immaare@yahoo.com
}

Received: March 24, 2015

Accepted: April 7, 2015 Online Published: May 16, 2015

doi:10.5430/jct.v4n1p167

URL: http://dx.doi.org/10.5430/jct.v4n1p167

\begin{abstract}
The purpose of the study was to investigate Junior High School science teachers' knowledge about contextualised science instruction. The study employed descriptive survey design to collect data. A test, Test of Science Teacher Knowledge of Contextualised Science Instruction was developed and administered to collect data on teachers' knowledge of contextualised science instruction from 204(180 males and 24 females) Junior High School science teachers. Descriptive and correlational data analyses were performed on the data collected. Some key findings that emerged in the study were: Majority of the teachers' knowledge about contextualised science instruction was weak but correlated positively and significantly with their highest professional qualification. A number of recommendations were made to the Ministry of education and Ghana Education Service: A policy statement should be made in the curriculum to indicate that science teaching should be contextualised. Another policy should be fashioned to compel institutions that train science teachers to include contextualisation of science instruction in their science methodology courses.
\end{abstract}

Keywords: contextualisation; contextualised science instruction; contextualised science instructional strategies; junior high school; science teachers; teachers' knowledge of contextualised science instruction

\section{Introduction}

The main goals of the Ghanaian Junior High School (JHS) science curriculum include creating a scientific and technological culture among Ghanaians and to make every Ghanaian citizen a scientific and technological literate (Curriculum Research and Development Division [CRDD], 2007; Ministry of Environment, Science and Technology, 2001, 2009). The science teachers are to relate the science content to the cultural and social milieu so that their pupils can apply the knowledge to solve societal problems (CRDD, 2007). Problems occur when the student is unable to identify what knowledge is needed to address a problem outside the (classroom) context in which it was taught (Smith, 2010). According to Smith when students are taught in a context that closely resembles the situation in which they will have to apply the information a greater chance of transfer of learning occurs. Transfer of learning from teaching setting to another and/or to real life situations may increase when science teachers use contextualised instructional strategies.

According to the Merriam-Webster Dictionary (2001), to contextualise means to place (as a word or activity) in a context. A context is defined as the interrelated conditions in which something exists or occurs. Contextualising then refers to looking at something in the setting or situation in which it is used or developed. With regard to science education, the 'some things' to be contextualised are the ideas, concepts, phenomenon and processes used to investigate and explain the world around us. Building from this definition, contextualising science instruction refers to the utilization of particular situations or events that occur outside of science class or are of particular interest to students to guide the presentation of science ideas and concepts (Rivet \& Krajcik, 2008; Smith, 2010). Linn and colleagues (Davis, \& Linn, 2000; Linn, \& His, 2000) also describe contextualised instruction as a process of knowledge integration which uses the ideas that students hold prior to instruction as the building blocks to an active process of linking, connecting, distinguishing, organizing, and structuring understandings of scientific phenomena. Therefore, contextualised teaching is a process of relating subject matter content to meaningful situations that are relevant to students' lives. 
Proponents of contextualised teaching feel that students who learn in a contextual environment are simultaneously introduced to the relevance of the content taught, which commensurately improves motivation (Baker, Hope, \& Karandjeff [as cited in Shan, 2011]; Schell \& Black [as cited in Shamsid-Deen, \& Smith, 2006]). As such, contextual teaching and learning has the potential to motivate students to make the connections between the demands of the classroom and their own personal goals and aspirations.

Again, in both developing and developed countries, science education teachers and curriculum developers are well aware that students are more likely to be interested in the science being taught at school if they can see how it relates to what they do in their daily lives (George, \& Lubben, 2002). Contextualisation of science curriculum must therefore be provided by the school and the teacher.

The benefits of contextualised science instruction espoused above are worthy of consideration in any national science curriculum. In Ghana the Junior High School science curriculum supports contextualised science instruction by way of the learner-centred instructional strategies contained in it. The teacher is to avoid teacher-centred teaching methods and rather emphasise "participatory teaching and learning in his/her lessons" (CRDD, 2012, p. ix). In line with this the Junior High School science syllabus (CRDD, 2012) has a range of child-centred interactive and participating methods. Some of these are: group work, demonstrations by pupils, class discussions, role-play, fieldtrips and project work. These are major contextual science instructional and learning practices which involve relating the science content to the context of real situations and problem solving (Shamsid-Deed, \& Smith, 2006). There is however a dearth of literature both internationally and locally. In the international front, most studies reviewed on contextualised science instruction are basically on implementing curriculum reforms that intend to make science teaching and learning relevant to the learner (Rivet, \& Krajcik, 2008). The only reported case was a study carried out by Shamsid-Deen and Smith (2006) to determine the level of knowledge family and consumer sciences teachers had on contextual teaching and learning practices. Locally, there is limited information on Ghanaian teachers' knowledge of learner-centred instructional strategies despite their promotion in past and present science syllabi for Junior High School level of education in Ghana (CRDD, 2001, 2007, 2012). Some researchers reported cases of child-centred teaching approaches (Akyeampong, 2001) and use of context in science teaching (Akyeampong, Ampiah, Fletcher, Kutor, \& Sokpe, 2000) in Ghanaian classrooms. These are glimpses of contextualised science instruction. But what was not clear in these studies was how knowledgeable the teachers were on contextualised science instruction. The success of this instructional approach would depend on the science teachers' knowledge about it and its implementation. Therefore for contextualisation of science instruction to be meaningful in Ghanaian Junior High Schools, there is the need to find out the science teachers' knowledge of contextualised science instruction and the factors influencing the latter. The researcher addressed this by investigating the current status of science teachers' knowledge of contextualised science instruction in Ghana. In addition, the study investigated the influence of teachers' academic and professional qualifications and years of teaching experiences on their knowledge of contextualised science instruction. The outcome of the study would offer avenues for proper contextualisation of science teaching and learning in Ghana. The following research questions were addressed:

1. How knowledgeable are Junior High School science teachers about contextualised science instruction?

2. What is the relationship between Junior High School science teachers' background factors (academic and professional qualifications and years of teaching experience) and their knowledge of contextualised science instruction?

\section{Literature Review}

Meaningful learning requires a connection between the learners' prior knowledge and the learning tasks provided by the teacher. It also requires the teacher to link new science concepts to the pupils' own experiences. This is because learning occurs as pupils try to make sense of what is taught by trying to fit it within their own experiences. To do this though, teachers need to have a clear idea of what the pupils already know and understand (Kennedy, 1998). The provision of this connection by the teacher depends on the teacher's competence in a number of critical domains discussed below.

Research on teacher subject knowledge indicates that teacher's knowledge of subject matter influences instructional practices across subject areas and at different grade levels (Brophy, 1998; Lee, 1995; Shulman, 2000). Without the essential base of subject matter, teachers are simply unable to produce effective instruction (Khwaja, 2002). In addition to an essential content base, effective instruction also requires teachers to transform and represent their knowledge in ways that the student can understand and appreciate (Lee, 1995). It has been found out that teachers 
who possess these qualities engage in class activities that facilitate students learning (Roth, Anderson \& Smith [as cited in Lee, 1995]; Tobin, \& Fraser, 1990). In contrast, teachers with weak subject matter knowledge rely heavily on the textbook as the primary source of subject matter content (Ball, \& Feiman-Nemser, 1988) and tend to minimise students participation in a class discussion. Therefore the teachers' knowledge of subject matter and pedagogy shape how the teacher might respond to students' questions and inquiries as the lesson unfolds in the science classroom (Crawford, 2007).

In contextualised science instruction there is the need for the JHS science teachers to understand strategies involved in learner-centred teaching approaches. They also need to move away from teacher-centred to learner-centred approaches. This requires teachers to question their traditional subject matter and classroom routines. This is because new teaching or innovative methods are pedagogical challenges (Ajibola, 2008). The teachers need to understand the new content and new methods that accompany such innovations. Yet, the implementation of learner-centred science teaching approaches, including contextualised science instruction, in Ghana has not been taken into consideration by early research projects. It has also been observed that in most innovative teaching methods used in science classrooms, teachers' knowledge have not been investigated sufficiently in the early stages (Halawah, 2008). This may be because of paucity of instruments to measure teachers' knowledge about these innovative approaches. This study intends to fill the gap.

Science teachers' views about teaching and learning shape their interpretation of curricular and instructional approaches. Similarly, the teachers' knowledge about contextualised science instructional strategies is likely to influence their practices of contextualised science instruction. Also, if the teachers' knowledge of other curricular demands are inadequate to meet the new content associated with contextualised science instruction, then they may be reluctant to implement it. Therefore, any attempts to contextualise science instruction in Ghana and elsewhere will, first have to consider other factors from the perspective of the science teacher. Again, if science teaching is to lead to enculturation of science among Ghanaian society (CRDD, 2012; Ministry of Environment, Science and Technology, 2001, 2009) then it is vital to find out how knowledgeable the Junior High School science teacher is about contextualised science instruction. This study was set up to investigate that.

\section{Methodology}

This study was carried out in the Upper West Region of Ghana. It was part of a larger study that investigated Junior High School (JHS) science teachers' attitude towards and their knowledge and practice of contextualised science instruction. The study employed an exploratory descriptive survey research design to investigate JHS science teachers' knowledge of contextualised science instruction. To be able to do this, there was the need to provide descriptive information on the teachers' knowledge of contextualised science instruction. This called for the gathering of standardized information by using the same instruments and questions for all participants. Also to be able to make generalizations about JHS teachers' knowledge of contextualised science instruction it was necessary to gather data from a wide population of JHS science teachers. A survey study has the advantage of being able to tap into the thinking of large representative samples of teachers (Creswell, 2009; Patton, 2002).

\subsection{Sample}

Convenience sampling method was used to select a sample of 204 (24 females and 180 males) science teachers from 288 Junior High Schools in the Upper West Region of Ghana for the study. Convenience sampling saves time, money and efforts but it is lowest in credibility (Patton, 2002). The sample may not be representative of the population. However, in this study the subjects are more or less representative of JHS science teachers in Ghana. This is because the teachers had similar professional training from the initial teacher training colleges. They also use similar prescribed science curriculum materials provided by the Ghana Education Service.

The choice of JHS level of education for the study was based on the fact that it is the terminal point of formal education for most pupils. It is at this point that science knowledge and attitudes need to be strengthened so that pupils who are not able to go beyond the JHS level would have acquired some scientific knowledge and skills which they could use to interact favourably with their environment. It is also here that science knowledge is precipitated and forms a spring board for those pupils who may proceed to the senior high schools or technical schools to pursue science and science-related programmes.

\subsection{Instrumentation}

The instrument used to collect data for the study was a test, Test of Science Teacher's Knowledge of Contextualised Science Instruction. The test was to find out whether the respondents had competencies in science content and the 
ability to use contextualised science instructional strategies to make the science content being taught meaningful and relevant to their pupils. The test consisted of six items on various concepts on change of state of matter (exemplified by the water cycle) and light. Three items (1,2 and 3) were on change of state of matter. Item 1 was on melting and freezing while items 2 and 3 were on condensation but each described a different scenario.

Item 4 was on reflection of light exemplified by how objects are seen while item 5 was on dispersion of light exemplified by the formation of rainbow. Item 6 was on formation of shadows exemplified by formation of eclipse. The test items were set based on some common misconceptions pupils have about change of state of matter and light and unscientific cultural beliefs about some natural occurrences such as formation of rainbow and eclipse.

The test items were presented in a form of scenarios in classroom situations where pupils were alleged to have made statements that contradicted the scientific understanding of the concepts being taught. An example of the items: You are teaching a lesson about 'change of state' of water and 'condensation', using a glass cup full of iced water, to junior high school form one class. One of the pupils, Salia, puts up his hand and says: 'Water drops on the outside of the glass cup with iced water, is water that seeps through the glass cup'. Comment on Salia's statement. What would you say in reply to Salia and what would you do to change his idea (and others like him) about the 'water drops on the outside of the glass cup full of iced water'?

The test items were designed to shed light on how participants would express their content knowledge in a contextualised manner (for example, to link the science concepts with pupils' prior knowledge) to enable their pupils understand the concepts in their scientific sense or context. The participants were therefore expected to indicate whether the pupils' comments on the concept(s) expressed a scientific view or not and then to proceed to indicate how the pupils' incorrect or alternative conceptions may be handled to effect the scientific understanding of the science concepts in the pupils. They were also expected to refer to some of the following categories of contexts where appropriate: (a) pupils' prior knowledge (b) experiences from previous classroom activities, (c) pupils' daily experiences' (d) possible pupils' misconceptions on the science concepts indicated in the items, e) suggesting possible class activities or discussions, and (i) challenging pupils' responses.

The responses of the participants were scored on the basis of the categories of contexts listed. A point was awarded where reference was made to any one relevant category of contexts. The total score of a respondent on an item ranged from zero point to five points.

The test items and the scheme for scoring participants' responses to the items were subjected to peer-review and experts' comments to determine their face and content validity. The test was further subjected to a pilot test with 100 Junior High School science teachers who were not involved in the study to improve its face and content validity of the instrument. Experts' comments and results of the analysis of the participants' responses led to modification of test items which failed to adequately elicit the intended responses from the participants. Such items were reworded to address the inadequacy. For example, some of the pilot sample's responses to item 2 suggested that a container with water was put in a fridge instead of the iced water poured into the container and used to illustrate condensation. The container was replaced with a glass cup and the scenario was then modified to include 'a 'glass cup filled with iced water'. The final instrument consisted of two sections. The first section was used to collect background (academic and professional qualifications, levels of JHS taught/being taught and years of teaching experience) data on the participants and the second section constituted the test.

\subsection{Data Collection Procedure}

Permission was obtained from the Headmasters/Headmistresses of the Junior High Schools involved in the study through their respective Regional and District/Municipal Directors of Education to administer the instrument in the schools. The researcher solicited the assistance of circuit supervisors to administer the test. The participants were invited to meet the researcher at their respective District or Municipal directorates of the Ghana Education Service. The consent of the teachers was sought to participate in the study. They were also assured of the confidentiality of their participation in the study and their participation in the study would neither affect their status as science teachers nor be used for purposes of promotion. So the participants responded anonymously to the test.

To improve the reliability of their responses to the items the participants were assured that there were no right or wrong answers to the test items and that the researcher simply wanted to understand their position on a number of issues about science teaching. The score for an item ranged from zero to 5, with the latter as the maximum score. So the maximum score for each respondent would be 30 .

\subsection{Data Analysis}

Descriptive statistics and correlational test analysis functions of the soft ware, SPSS version 16 (Green, \& Salkind, 
2008) were used to analyse the data. The descriptive statistics function was used to organise the data on background information of the participants into percentages and used to construct their academic and professional profiles. Also, the participants' total scores for each test item, percentage frequency distribution of their scores, the percentage mean scores and standard deviations were determined. Spearman Brown correlation test analysis was used to determine any correlation between the teachers' knowledge of contextualised science instruction and their background factors. Though the test is less efficient compared to its parametric counterpart it has the advantage over the latter when nominal and continuous data, as in this case, are involved (Kothari, \& Garg, 2014). Again, though the sample size is greater than 30, it was purposively and not randomly selected hence normal distribution of the data could not be substantiated.

\section{Results}

\subsection{Background Information on the Participants}

The background information on the participants is presented in Table 1.

Table 1. Background Information on the Participants

\begin{tabular}{|c|c|c|}
\hline Variable & Frequency & $\%$ frequency \\
\hline $\begin{array}{ll}\text { Sex } & \text { Male } \\
& \text { Female }\end{array}$ & $\begin{array}{c}180 \\
18\end{array}$ & $\begin{array}{l}88.24 \\
11.76\end{array}$ \\
\hline Total & 204 & 100.0 \\
\hline Academic Qualification & & \\
\hline Secondary school certificate & 184 & 91.50 \\
\hline Diploma certificate & 7 & 3.50 \\
\hline Advance technical certificate & 4 & 2.00 \\
\hline Bachelor degree & 6 & 30.00 \\
\hline Total & 201 & 100 \\
\hline Professional Qualification & & \\
\hline Teacher's Certificate A & 133 & 78.60 \\
\hline Diploma certificate & 30 & 17.80 \\
\hline B. Ed (Education) & 3 & 1.80 \\
\hline Technical teacher's certificate & 3 & 1.80 \\
\hline Total & 169 & 100 \\
\hline Years of Teaching Experienc & & \\
\hline $0-3$ & 84 & 43.52 \\
\hline 4-6 & 39 & 20.21 \\
\hline $7-10$ & 57 & 29.53 \\
\hline More than 10 & 13 & 6.74 \\
\hline Total & 193 & 100.0 \\
\hline
\end{tabular}

Majority of the participants $(184,91.5 \%)$ ) obtained secondary school certificate as their highest academic qualification. Seven and four participants obtained Diploma certificate and Advance technical certificate respectively while and the rest $(6,30 \%)$ obtained Bachelor of Science Degree. Three of the participants did not indicate their academic qualification which explains the total number of 201 instead of 204 participants. About $83 \%(169)$ and $17 \%$ (35) of the participants were professional and non-professional teachers respectively. The professional group obtained either one of the different categories of professional qualification. Almost $79 \%$ (133) of the participants obtained Teacher's Certificate 'A' while, $17 \%$ (30) of them obtained Diploma certificate. Also, about $2 \%$ (3) of the participants obtained either Bachelor in Education degree or Technical teacher's certificate.

The participants also had varied years of teaching experience, which ranged between 3 and 17 years with a mean of 2 years. Almost $44 \%$ (84) of the participants had between 0 and 3years of teaching experience while only $13(6.7 \%)$ taught for more than ten years. Eleven participants did not indicate the number of years of teaching which explains the total number of 193 instead of 204 participants. Further details are provided in Table 1.

4.2 Research Question 1: How Knowledgeable are Junior High School Science Teachers about Contextualised Science Instruction?

The percentage frequency distribution of the participants' scores on the test is presented in Table 2 . 
Table 2. Percentage Frequency Distribution of Junior High School Science Teachers' Scores on Knowledge about Contextualised Science Instruction

\begin{tabular}{rccc}
\hline Test scores & \% Frequency distribution of scores & Test scores & \%Frequency distribution of scores \\
\hline 1 & $0.5(1) \mathrm{a}$ & 10 & $8.8(18)$ \\
2 & $1.0(2)$ & 11 & $7.8(16)$ \\
3 & $2.5(5)$ & 12 & $5.4(11)$ \\
4 & $2.5(5)$ & 13 & $4.9(10)$ \\
5 & $6.9(14)$ & 14 & $3.9(8)$ \\
6 & $11.3(23)$ & 15 & $2.9(6)$ \\
7 & $10.8(22)$ & 16 & $0.5(1)$ \\
8 & $18.1(37)$ & 17 & $1.0(2)$ \\
9 & $9.8(20)$ & 19 & $1.5(3)$ \\
\hline Total (\%) & & $\mathbf{1 0 0 ( 2 0 4 )}$ \\
\hline
\end{tabular}

${ }^{\mathrm{a}}$ Frequency counts in parentheses; overall Mean Score $=8.8, \mathrm{SD}=3.3$

The scores ranged from 1 to 19 with a mode of 8 and an overall mean score of 8.8 ( $\mathrm{SD}=3.3$ ). The performance of the participants on the test was generally poor. About 63\% (129) of the participants obtained scores below 10 while only about $37 \%$ (75) of participants obtained scores between 10 and 19 . Again, only $6 \%$ of the participants got $50 \%$ of scores (i.e. 15 and above). The results of the analysis indicate that knowledge about contextualised science instruction is very low among the JHS science teachers. That is, they lacked the competencies, both in science content knowledge and contextualised science instructional strategies to handle the pupils' incorrect scientific ideas and/or misconceptions indicated in the test items.

The percentage frequency distribution of the participants' score on each test item was determined to find out how they performed on the item. The mean scores and standard deviations of the total score for each item were also determined. The results of the analysis are presented in Table 3.

Table 3. Percentage Frequency Distribution, Mean scores and SDs of Junior High School Science Teachers' Scores on Science Teacher Knowledge of Contextualised Science Instruction

\begin{tabular}{|c|c|c|c|c|c|c|c|c|c|}
\hline \multirow[t]{2}{*}{ Test item } & \multicolumn{6}{|c|}{$\%$ frequency distribution of Scores } & \multirow[t]{2}{*}{ Number of participants } & \multirow[t]{2}{*}{ MS } & \multirow[t]{2}{*}{ SD } \\
\hline & 0 & 1 & 2 & 3 & 4 & 5 & & & \\
\hline 1 & 15.2 & 21.6 & 44.1 & 15.7 & 2.5 & 1.0 & 204 & 1.7 & 1.0 \\
\hline 2 & 49.5 & 28.4 & 13.2 & 8.3 & 0.5 & - & 204 & 0.8 & 1.0 \\
\hline 3 & 13.2 & 27.9 & 34.6 & 16.7 & 6.9 & 0.5 & 204 & 1.8 & 1.1 \\
\hline 4 & 46.3 & 37.9 & 13.8 & 1.0 & 1.0 & - & 204 & 0.7 & 0.1 \\
\hline 5 & 9.8 & 34.3 & 33.3 & 20.1 & 2.5 & - & 204 & 1.7 & 1.0 \\
\hline 6 & 4.9 & 21.6 & 34.8 & 35.3 & 3.4 & - & 204 & 2.1 & 1.0 \\
\hline
\end{tabular}

Grand overall $\mathrm{MS}=1.5 ; \mathrm{SD}=1.0$

The item mean scores ranged from 0.7 to 2.1 with grand overall of mean score of 1.5 and standard deviation of 1.0. Thus, most of the mean scores clustered around the sample mean. Also, the mean scores were far below the mean score of 5.0 for the test.

The scores clustered between zero and three. The percentage frequencies ranged from $0.5 \%$ to $49.5 \%$ and over $90 \%$ of the sample obtained scores between zero and three for each item. Only $1.5 \%$ (3) of the participants obtained the maximum score of 5 on items 1 and 3 . Close to $50 \%$ of the participants obtained zero score for items $2(49.5 \%)$ and $4(46.3 \%)$. The participants' performance on the test items was therefore poor. This is further indicated by an overall mean score of $1.5(\mathrm{SD}=1.0)$. This suggested that the participants' knowledge about contextualised science instruction was very low. This might be attributed to their poor content knowledge on the concepts used in the test and their inability to use contextualised science instructional strategies to address the pupils' incorrect ideas and/or misconceptions.

4.3 Research Question 2: What is the relationship between Junior High School science teachers' background factors (academic and professional qualifications and years of teaching experience) and their knowledge about contextualized science instruction?

The background factors of the participants were used as basis for organising the test scores of the participants. This was to facilitate analysis and interpretation of the test scores with regard to possible influence of the factors on the JHS science teachers' knowledge about contextualised science instruction. The academic, professional and the years 
of teaching experience clusters consisted of four levels each. The levels in each cluster had disproportionate number of participants and so it was not statistically appropriate to compare their performances on the test. The problem was solved by determining the relative percentage mean scores instead of mean scores. The split and descriptive functions of SPSS software version 16 were used to determine each cluster's mean score and the relative percentage mean score for each level of the clusters. The overall percentage mean score for each cluster was also determined. The results of the analysis for each cluster are presented in a table.

\subsubsection{Academic Qualification and Knowledge about Contextualised Science Instruction}

Table 4 presents the performance of the participants on the test by academic qualification.

Table 4. Relative Percentage Mean Scores and SD by Academic Qualification of Junior High School Science Teachers' Scores on Knowledge about Contextualised Science Instruction

\begin{tabular}{lcll}
\hline Academic qualification & $\begin{array}{c}\text { Number of JHS Science } \\
\text { Teachers }\end{array}$ & Relative \% MS & SD \\
\hline Secondary school certificate & 184 & $25.1(9.1)$ & 3.3 \\
Diploma certificate & 7 & $27.1(9.8)$ & 2.6 \\
Advance technical certificate & 4 & $25.7(9.3)$ & 5.1 \\
Bachelor degree & 6 & $22.1 .(8.0)$ & 3.4 \\
\hline & & Aver Rel. \%. & Aver SD = 3.6 \\
Total & $\mathbf{2 0 1}$ & MS $=24.0(8.7)$ & \\
\hline
\end{tabular}

Note *mean scores in parenthesis

All the participants except three indicated their academic qualification status. This explains the total number of 201 instead of the actual sample size of 204. Those with Secondary School certification constituted largest number of participants $(184,91.5 \%$ ) while the Advance technical certificate holders constituted the least $(4,2.0 \%)$.

The relative percentage mean scores of the levels in the academic cluster were quite close. They ranged from 22.1 to 27.1 with three of them above the cluster relative \% mean score of $24.0(\mathrm{SD}=3.6)$. The SDs ranged from 2.6 to 5.1. The highest relative percentage mean score $(27.1, \mathrm{SD}=2.6)$ was obtained by participants in the Diploma certificate group while the lowest relative \% mean score (22.1, SD=3.4) was registered by the Bachelor degree group.

4.3.2 Professional Qualification and Knowledge about Contextualised Science Instruction

Table 5 shows the performance of the professional cluster on the test.

Table 5. Relative Percentage Mean Scores and Standard Deviations by Professional Qualification of Junior High School Science Teachers' Scores on Knowledge about Contextualised Science Instruction

\begin{tabular}{lcll}
\hline Professional qualification & $\begin{array}{c}\text { Number of JHS } \\
\text { Science Teachers }\end{array}$ & $\begin{array}{l}\text { Relative\% } \\
\text { Mean score }\end{array}$ & SD \\
\hline Teacher's Certificate A & 133 & $23.3(8.9)$ & 3.4 \\
Diploma certificate & 30 & $26.0(9.9)$ & 3.3 \\
B. Ed (Education) & 3 & $28.9(11.0)$ & 6.9 \\
Technical teacher's certificate & 3 & $21.8(8.3)$ & 6.0 \\
\hline Total & $\mathbf{1 6 9}$ & $\begin{array}{l}\text { Aver Rel. \% } \\
\text { mean }=\mathbf{2 4 . 9}(\mathbf{9 . 5})\end{array}$ & Aver SD = 4.9 \\
\hline
\end{tabular}

Note *mean scores in parenthesis

The professional cluster had169 participants distributed among four levels. The Teacher's Certificate 'A' constituted the largest level with 133 (78.7\%) participants followed by Diploma in Education (30, 17.8 \%). The other two levels had three participants each.

The percentage mean scores of the different levels of the cluster were quite close and they ranged from 23.3 to 28.9 with two above the cluster's average relative $\%$ mean score of $24.9(\mathrm{SD}=4.9)$. The highest relative $\%$ mean score $(28.9, \mathrm{SD}=6.9)$ was obtained by the Bachelor degree in Education level while the lowest relative $\%$ mean score $(26.0, \mathrm{SD}=3.3)$ was obtained by the technical level.

\subsubsection{Years of Teaching Experience and Knowledge about Contextualised Science Instruction}

Eleven of the participants did not indicate their years of teaching experience. This explains the total number of 193 instead of the actual sample size of 204 (Table 6). 
Table 6. Relative Percentage Mean Scores and Standard Deviations by Years of Teaching Experience of Junior High School Science Teachers' Scores on Knowledge about Contextualised Science Instruction

\begin{tabular}{llll}
\hline $\begin{array}{l}\text { Years of } \\
\text { teaching experience }\end{array}$ & $\begin{array}{l}\text { Number of JHS } \\
\text { science Teachers }\end{array}$ & Relative\% MS & SD \\
\hline $0-3$ & 84 & $25.5(9.3)$ & 3.5 \\
$4-6$ & 39 & $24.4(8.9)$ & 3.3 \\
$7-10$ & 57 & $24.7(9.0)$ & 3.2 \\
$>10$ & 13 & $25.5(9.3)$ & 2.8 \\
\hline Total & $\mathbf{1 9 3}$ & $\begin{array}{l}\text { Aver Rel.\% } \\
\text { MS }=\mathbf{2 4 . 4}(\mathbf{8 . 9})\end{array}$ & Aver SD $=\mathbf{3 . 2}$ \\
\hline
\end{tabular}

Note *mean scores in parenthesis

The participants with less than/or 3 years of teaching experience constituted the largest level (84) while the level of more than ten years of teaching experience had the least number of participants. The relative percentage mean scores of the different levels of years of teaching experience were also quite close. They ranged from 24.4 to 25.5. But for the first level (0-3 years), the relative percentage mean scores increased with corresponding increase in the number of years of teaching experience. The highest relative \% mean score $(25.5, \mathrm{SD}=2.8)$ and the lowest relative $\%$ mean score $(24.4, \mathrm{SD}=3.2)$ was obtained by the participants who had taught for more than ten years and six years respectively.

The preliminary data for all the background factors indicated that the different levels in each cluster of these factors had different levels of understanding about contextualised science instruction. A correlational analysis (Spearman Rho correlational test) was performed on the data to determine any correlation of the teachers' knowledge of contextualised science instruction with the teachers' background factors (academic and professional qualifications and years of teaching experience). The results of the analysis are shown in Table 7.

Table 7. Spearman Rho Correlations for Background Variables with Knowledge about Contextualised Science Instruction

\begin{tabular}{|c|c|}
\hline Variables & STKCSI \\
\hline STKCSIS & 1.00 \\
\hline Academic qualification & -.01 \\
\hline Professional qualification & $.21^{* \mathrm{a}}$ \\
\hline Years of teaching experience & -.03 \\
\hline
\end{tabular}

The results showed that only the professional qualification had a positive and statistically significant correlation ( $\mathrm{r}$ $=.21, \mathrm{p}<0.05$ ) with science teachers' knowledge of contextualised science instruction with a small coefficient of determination $\left(\mathrm{r}^{2}=.044\right)$ (Table 7). That is, the professional qualification accounted for $4.4 \%$ of the JHS science teachers' knowledge of contextualised science instruction. Nonetheless, it is an indication that a JHS science teacher's knowledge on contextualised science instruction might increase with improvement in professional qualification.

\section{Discussion}

One of the expected competencies of the JHS science teachers for contextualising science instruction is the teachers' knowledge about contextualised science instruction. This knowledge refers to the teacher's understanding and interpretation of the Junior High School science curriculum (content and process skills, and instruction) and their understanding of aspects of the pupil's cultural environment that are relevant for science instruction and how these play out during instruction. It also includes the teacher's knowledge of their pupils' prior knowledge and their previous classroom learning experiences. The teacher's knowledge of these aspects of the pupil will enable him/her to relate the science concepts to real contexts of the pupils. This will facilitate the pupil's understanding of the concepts. However, the results of the test indicated that majority of the teachers are not knowledgeable in contextualised science instruction.

The poor performance of the teachers on the test items may be explained by their poor science content knowledge, their incompetence in identifying and handling pupils' misconceptions and/or unscientific ideas. A cursory look at some of their responses showed that majority of teachers did not have the requisite content knowledge to correct the unscientific ideas inherent in the statements. Some of the teachers acknowledged some of the statements to be 
scientifically correct though such statements contained clear misconceptions or scientific incorrect ideas. For instance, some of them agreed with the statement that 'we see objects because they are illuminated by light'. They were not able to explain how objects are seen by humans. In another instance, the participants were asked to comment on a pupil's assertion that 'water drops formed on the outer surface of a glass cup containing iced water was water that seeped through the walls of the glass cup'. While some of the teachers used concepts such as adhesive and cohesive forces to explain how the water drops were formed on the surface, others stated that it was due to the 'porosity' of the glass cup which implied that the water seeped through the walls of the cup. These responses were more or less confirming the pupils' statement and manifested the teachers' poor knowledge on the process involved in condensation of water vapour when in contact with a colder surface. The findings also buttressed the assertion that without the essential knowledge base of subject matter, teachers are simply unable to produce effective instruction (Brophy, 1998; Grossman, Wilson, \& Shulman [as cited in Lee, 1995]).

Apart from their lack of the appropriate science content knowledge to comment on statements appropriately some of the JHS science teachers also failed to demonstrate the competencies required in contextualised instruction. They were unable to evaluate and build on the pupils' conceptual and cultural knowledge (Branford, Brown \& Cooking [as cited in Rivet \& Krajcik, 2003]) which were expressed in the statements during the science lessons. So they were unable to use appropriate contextualised instructional strategies to identify and handle pupils' unscientific ideas highlighted in the test items. The trend presented by the teachers' responses to some of the test items was that where the teacher had the appropriate content knowledge to correct the pupil, s/he failed to use the appropriate contextualised instructional strategies to do so. Such teachers neither commented on the possible sources of the unscientific ideas nor used the appropriate classroom practical activities to improve the pupils' understanding of the concepts. For instance, some teachers were able to explain the formation of a rainbow and an eclipse but failed to state the cultural basis of the unscientific ideas indicated in the statements (Item 5: A rainbow formed in the sky is a sign of a female python laying eggs; Item 6: But sir, an eclipse of the sun occurs when the moon swallows the sun). They also failed to suggest appropriate classroom activities to demonstrate the formation of the rainbow and the eclipse. The findings affirm Lederman's (1992) assertion that a teacher with limited knowledge about pupils' misconception in science cannot offer alternative, and helpful explanations, especially so if, the teacher has limited science content knowledge (Khwaja, 2002).

However, the professional JHS science teachers among the sample demonstrated adequate knowledge of contextualised science instruction. The teachers' professional qualification was the only background factor which correlated positively and significantly with the science teachers' knowledge about contextualised science instruction. The teachers of the diploma level group obtained the highest relative percentage mean score on the test.

Though correlation does not mean causation, one would expect a science teacher to improve upon his/her instructional strategies to make science more meaningful and relevant to the learners as s/he advances in the profession. The initial teacher training college programmes are designed to equip pre-service teachers with both science content knowledge and instructional skills through curriculum studies. While in the field they might have also benefitted from participating in workshops, science teachers' conferences and in-service training programmes on science teaching. These are likely to improve their instructional competencies to relate science content meaningfully to their pupils through tried out instructional strategies.

Also, some of the teachers had further professional training after their initial teacher training. So while in training at the higher institution of professional development, they were exposed further to new ways of teaching science through the methodology courses of the programme. This point is buttressed by the fact that the science teacher's knowledge of science and science curriculum hinge on more extensive experience of the science teacher (Brickhouse, 1990; Davies, 2003). So the professional training in the subject area might have contributed to the teachers' ability to comment on the pupils' statements and to suggest appropriate contextualised instructional strategies to handle the pupils' unscientific ideas or misconceptions. Researches which correlated formal science background with teaching found positive correlation (Davies, 2003; Smith \& Anderson, 1988). Smith and Anderson found a positive relationship between science background and use of demonstration and group and individual work. This was evidenced in the responses of the teachers with both higher academic and professional background in science. They made appropriate comments to the pupils' statement and suggested appropriate classroom activities to be carried out by the pupils to correct their own errors. Also, they commented appropriately on the sources of the pupils' unscientific ideas /misconception implied in the statements. The findings support earlier findings that, teachers who possess subject (content) matter and the ability to represent the subject matter to his/her pupils engage them in activities that facilitate learning (Khwaja, 2002; Roth, Anderson \& Smith [as cited in Lee, 1995]; Tobin \& Fraser, 1990). 
The finding that teachers with more than 10 years of teaching experience had the highest overall percentage mean score on knowledge of contextualised science instruction was unique. In previous studies reported by Shamsid-Deen and Smith (2006) concerning years of teaching experience and new teaching initiatives or educational reforms, teachers in later years of their career usually do not rate higher than other teacher groups. In this study, longevity may have contributed to the teachers experimenting with innovative instructional approaches and their subsequent use as suggested by Shamsid-Deen and Smith (2006).

\section{Conclusions and Recommendations}

The data from the test on JHS science teachers' knowledge about contextualised science instruction indicated that majority of the participants were not knowledgeable in contextualised science instruction. Apart from their lack of the appropriate science content knowledge to respond to the test items on the concepts tested they also failed to demonstrate the competencies required in contextualised instruction. They were unable to use appropriate contextualised instructional strategies to identify and handle pupils' unscientific ideas highlighted in the test items. However, the findings of the study also suggest that professional science teachers with more science content knowledge are more likely to teach in ways that help pupils construct knowledge. The professional qualification of the JHS science teachers was the only background factor which correlated positively and significantly with their knowledge of contextualised science instruction.

It was evident also that a good number of the teachers lacked both science content knowledge and pedagogical content knowledge required for contextualised science instruction. These need to be addressed if the Ghanaian JHS science teacher is to use the participatory teaching methods and play the role of a facilitator during science instruction as suggested in the JHS science teaching syllabus.

It appears not much emphasis is placed on equipping teacher trainees skills for contextualised science instruction. The situation calls for a serious curriculum review and possible reform of the current science teacher professional training curriculum. It is recommended to the Ministry of Education and Ghana Education Service to fashion a policy to compel institutions that train science teachers to include contextualisation of science instruction in their science methodology courses. For the meantime, in-service days at educational directorates would be opportunities to enhance science teachers' knowledge of contextualised science instruction and promote its implementation at the junior high school level.

\section{References}

Ajibola, M. A. (2008). Innovations and curriculum development for basic education in Nigeria: policy priorities and challenges of practice and implementation. Research Journal of International Studies, 8, 51-58.

Akyeampong, K. (2001). Initial teacher training in Ghana-Does it count?-A country report Muster Research Report No. 1 Paper Sussex: Centre for International Education, Department of Education, University of Sussex. Retrieved from www.sussex.ac.uk/education/document/muster-discussionpaper17

Akyeampong, K., Ampiah, J., Fletcher, J., Kutor, N., \& Sokpe, B. (2000). Learning to teach in Ghana: An evaluation of curriculum delivery MUSTER Discussion Paper No. 17. Sussex: Centre for International Education, Department of Education, University of Sussex. Retrieved from r4d.dfid.gov.uk/PDF/outputs/skillsForDev/Educationalpaper49bpdf

Ball, D. L., \& Feiman-Nemser, S. (1988). Using textbooks and teachers' guides: what beginning elementary teachers learn and what they need to know. Curriculum Inquiry, 18, 401-423. http://dx.doi.org/10.2307/1179386

Bartholomew, H., \& Osborne, J. (2004). Teaching students 'ideas about science': Five dimensions of effective practice. Science Education, 36, 655-682. http://dx.doi.org/10.1002/sce.10136

Brickhouse, N. W. (1990). Teacher beliefs about the nature of science and their relationship to classroom practices. Journal of Teacher Education, 41(3), 53-62. http://dx.doi.org/10.1177/002248719004100307

Brophy, J. (1998). Motivating students to learn. Boston: McGraw-Hill.

Crawford, B. A. (2007). Learning to teach science as inquiry in the rough and tumble of practice. Journal of Research in Science Teaching, 4(4), 613-642. http://dx.doi.org/10.1002/tea.20157

Creswell, J. W. (2009). Research design: Qualitative, quantitative and mixed methods approach (3 ${ }^{\text {rd }}$ ed.). Thousand Oaks, California: SAGE Publications. 
Curriculum Research Development Division (2001). Teaching syllabus for Science (Junior High School). Ghana, Accra: Ministry of Education.

Curriculum Research Development Division (2007). Teaching syllabus for science (junior high school). Ghana, Accra: Ministry of Education.

Curriculum Research Development Division (2012). Teaching syllabus for science (junior high school). Ghana, Accra: Ministry of Education.

Davis, E. A. (2003). Knowledge integration in science teaching: Analyzing teachers' knowledge development. Research in Science education, 34, 21-53. http://dx.doi.org/10.1023/B:RISE.0000021034.01508.b8

Davis, E. A., \& Linn, M. C. (2000). Scaffolding students' knowledge integration: Prompts for reflection in KIE. International Journal of Science Education, 22(8), 819-837. http://dx.doi.org/10.1080/095006900412293

George, J. M., \& Lubben, F. (2002). Facilitating teachers' professional growth through their involvement in creating context-based materials in science. International Journal of Educational Development, 22, 695-672. http://dx.doi.org/10.1016/S0738-0593(01)00033-5

Green, S. B., \& Salkind, N. J. (2008). Using SPSS for window and macintosh: Analysing and understanding data (5 ${ }^{\text {th }}$ ed.). Upper Saddle River, NJ: Pearson/Prentice Hall.

Halawah, J. (2008). Factors influencing perspective teachers' attitude towards teaching. University of Sharjah Journal of Humanities and Social Sciences, 5(1), 1-17.

Kennedy, M. M. (1998). Educational reform and subject matter knowledge. Journal of Research in Science Teaching, 35(3), 249-263. http://dx.doi.org/10.1002/(SICI)1098-2736(199803)35:3<249::AID-TEA2>3.0.CO;2-R

Khwaja, C. C. (2002). The role of subject knowledge in the effective teaching of primary science. Doctoral school Poster Conference, Institute of Education, University of London, U. K., Dec. 2002.

Kothari, C. R., \& Garg, G. (2014). Research methodology: Methods and techniques (3 ${ }^{\text {rd }}$ ed.). India, New Delhi: New Age International (P) Limited, Publishers.

Lederman, N. G. (1992). Students' and teachers' conceptions of the nature of science: A review of the research. Journal of Research in Science Teaching, 29(4), 331-359. http://dx.doi.org/10.1002/tea.3660290404

Lee, O. (1995). Subject matter knowledge, classroom management, and instructional practices in middle school science classrooms. Journal of Research in Science Teaching, 32(4), 423-440. http://dx.doi.org/10.1002/tea.3660320409

Linn, M. C., \& His, S. (2000). Computers, Teachers, Peers: Science learning partners. Mahwah, NJ: Lawrence Erlbaum Associates.

Merriam-Webster Collegiate Dictionary (2000). Retrieved November 2007 from http://www.merriam-webster.com/home.htm

Ministry of Environment, Science and Technology (2001). National science and technology policy document. Ghana, Accra: Author

Ministry of Environment, Science and Technology (2009). National science and technology policy document. Ghana, Accra: Author.

Patton, M., Q. (2002). Qualitative research and evaluation methods ( $3^{\text {rd }}$ ed). London: Sage Publications, Inc.

Rivet, A. E., \& Krajcik, J. S. (2003). Contextualising instruction: Leveraging students' prior knowledge and experiences to foster understanding of middle school science. A paper presented at the Annual meeting of the National Associations for Research in Science Teaching (NARST), Philadelphia, PA March, 2003. http://dx.doi.org/10.1002/tea.20203

Rivet, A. E., \& Krajcik, J. S. (2008). Contextualising Instruction: Leveraging students' prior knowledge and experiences to foster understanding of middle school science. Journal of Research in Science Teaching, 45(1), 79-100.

Schneider, R. M., \& Krajcik, J. (2002). Supporting science teacher learning: The role of educative curriculum materials. Journal of Science Teacher Education, 13(3), 221-245. http://dx.doi.org/10.1023/A:1016569117024

Shamsid-Deen, I., \& Smith, B. P. (2006). Integrating contextual teaching and learning practices into the family and consumer sciences teachers' curriculum. Journal of Family and Consumer Sciences Education, 24(1), 14-27. 
Shan, Y. W. (2011). Contextualised teaching towards active learning. Centre for Development of Teaching and Learning Brief, 14(2), 1-3.

Shulman, L. S. (2000). Teacher development and teaching: Roles of domain expertise and pedagogical knowledge. $\begin{array}{lllll}\text { Journal of Applied Development } & \text { Psychology, } & 21(1), & \text { 129-135. }\end{array}$ http://dx.doi.org/10.1016/S0193-3973(99)00057-X

Smith, B. P. (2010). Instructional strategies in family and consumer sciences: Implementing the contextual teaching and learning pedagogical model. Journal of Family and Consumer Science Education, 28(1), 23-38.

Smith, E. L., \& Anderson, C. W. (1988). Plants as producers: A case study of elementary science teaching. Journal of research in science teaching, 21, 685-698. http://dx.doi.org/10.1002/tea.3660210703

Tobin, K., \& Fraser, B. (1990). What does mean to be an exemplary teacher? Journal of research in science teaching, 27(1), 3-25. http://dx.doi.org/10.1002/tea.3660270103 